\title{
Correction to: Experimental and theoretical investigations on temperature and voltage dependence of an Au/AZO thin-film Schottky diode
}

\author{
Aliasghar Shokri ${ }^{1} \cdot$ Laya Dejam ${ }^{1}$
}

Published online: 6 February 2019

(c) The Author(s) 2019

\section{Correction to: International Nano Letters https://doi.org/10.1007/s40089-018-0261-3}

The original version of this article unfortunately contains an error in Equation 3.

The correct Equation is given below:

$$
J_{\text {th }}=A^{*} T^{2} \exp \left(-\frac{\Phi_{\mathrm{B}}}{k_{\mathrm{B}} T}\right)\left[\exp \left(\frac{e\left(V_{\mathrm{a}}-A_{\mathrm{c}} J_{\mathrm{th}} R_{\mathrm{s}}\right)}{n k_{\mathrm{B}} T}\right)-1\right] .
$$

The original article has been corrected.

Open Access This article is distributed under the terms of the Creative Commons Attribution 4.0 International License (http://creativeco mmons.org/licenses/by/4.0/), which permits unrestricted use, distribution, and reproduction in any medium, provided you give appropriate credit to the original author(s) and the source, provide a link to the Creative Commons license, and indicate if changes were made. 